\title{
Numerical Analysis and Computerized Identification of the Yeast Genera Candida and Torulopsis
}

\author{
By I. CAMPBELL \\ Department of Brewing and Biological Sciences, Heriot-Watt University, \\ Edinburgh $E H \mathrm{I}$ I $H X$
}

(Received 27 January 1975; revised 3 April 1975)

SUMMARY

Numerical analysis of the published standard descriptions of 104 species of Candida and 48 species of Torulopsis suggested that the number of species should be reduced to 78 and 33 respectively. Four examples are noted of closely matched species differing in ability to assimilate nitrate; these species may be combined as nitrate-variable species. Although the ability to form pseudomycelium is the only important difference between the genera, only three examples were noted of Candida and Torulopsis species sufficiently closely matched to be regarded as synonymous. Close relationships with species of the perfect genera were more common. A system, derived from the results of the analysis, is described for computerized identification of species of both genera.

\section{INTRODUCTION}

The genera Candida and Torulopsis were described by van Uden \& Buckley (1970) as a heterogeneous collection of asporogenous yeasts which could not be classified conveniently elsewhere. Both genera therefore include yeasts of widely different properties with respect to morphology, fermentation, and production of a true mycelium or pseudomycelium. Production of a pseudomycelium is an unsatisfactory criterion for distinguishing between the two genera, and van Uden \& Buckley noted a number of transitional species with poorly developed pseudomycelia.

Previously published numerical analyses of the genera Candida and Torulopsis have concerned only a restricted range of species, e.g. Candida albicans and related species (KockováKratochvílová et al. 1967; Kocková-Kratochvílová \& Ondrušová, 1972; Shechter, Landau \& Dabrowa, 1972), and a selection of 22 Torulopsis species (Kocková-Kratochvílová, 1973). Therefore an analysis of the published properties of all valid species of Candida and Torulopsis was attempted, by the system used previously for the genera Saccharomyces, Hansenula and Pichia (Campbell, 1972, 1973a).

\section{METHODS}

Characters for numerical analysis. The analyses were performed on the published descriptions of species by van Uden \& Buckley (1970), van Uden \& Vidal-Leiria (1970) and by authors who subsequently described new species. The 58 characters described in the study of Hansenula and Pichia (Campbell, 1973a) were reduced to 53 by elimination of spore characters for analyses limited to Candida and Torulopsis. However, the allocation of five taxonomic units to ascospores was later restored for comparison of Candida and Torulopsis with ascosporogenous genera of similar morphological and physiological properties. 
The standard properties of each species were described on 80-column punched cards (Campbell, 1972). Normally two cards were required to describe the limits of variability of a species, i.e. in one description all variable properties were scored positive and in the other description all variable properties were scored negative. Rarely-isolated species with no variable properties in the standard descriptions required only one card per species.

Calculation of the matching coefficient $S_{s m}$ (Sneath \& Sokal, 1973) was by the computer programs I and 2 described by Campbell $(1973 b)$, and the results were drawn as dendrograms in steps of $5 \%$ at the highest matching coefficient of the group.

Species for analysis. The 71 species of Candida described by van Uden \& Buckley (1970) and the 36 species of Torulopsis described by van Uden \& Vidal-Leiria (I970) were analysed. In addition, the following recently described species were included: Candida amylolenta (van der Walt, Scott \& van der Klift, I972), C. australis (Goto, Sugiyama \& Iizuka, 1969), C. boleticola (Nakase, 1971 a), C. bombi (Montrocher, 1967), C. butyri (Nakase, 1971 a), C. chilensis (Grinbergs \& Yarrow, 1970), C. chiropterorum (Grose \& Marinkelle, 1968), C. citrea (Nakase, 197I $b$ ), C. dendronema (van der Walt, Scott \& van der Klift, 1971 $a$ ), C. edax (van der Walt \& Nel, 1968), C. entomaea (van der Walt et al. 1971 a), C. fibrae (Nakase, I97 I c), C. fragicola (Nakase, 197I c), C. homilentoma (van der Walt \& Nakase, I973), C. hylophila (van der Walt et al. I97 I a), C. incommunis (Ohara, Nonomura \& Yamazaki, 1965), C. insectamans (van der Walt et al. 1972), C. insectorum (van der Walt et al. 1972), C. lactosa (Dwidjoseputro \& Wolf, 1970), C. naeodendra (van der Walt, Johannsen \& Nakase, 1973), C. nitrativorans (van der Walt et al. 1972), C. oleophila (Montrocher, 1967), C. pseudolipolytica (Blagodatskaya \& Kocková-Kratochvílová, 1973), C. quercuum (Nakase, 1971a), C. rugopelliculosa (Nakase, 197I b), C. silvanorum (van der Walt et al. 197 I a), C. silvicultrix (van der Walt et al. 1972), C. sorboxylosa (Nakase, 197 I b), C. steatolytica (Yarrow, 1969a), C. suecica (Rodrigues de Miranda \& Norkrans, 1968), C. tsukubaensis (Onishi, 1972), C. valdiviana (Grinbergs \& Yarrow, 1970), Torulopsis auriculariae (Nakase, I97 I c), T. bombicola (Spencer, Gorin \& Tulloch, 1970), T. dendrica (van der Walt et al. 1971 b), T. fragaria (Barnett \& Buhagiar, 197I), T. fructus (Nakase, I97I c), T. humilis (Nel \& van der Walt, I968), T. insectalens (van der Walt et al. I97 I b), T. kestoni (Scarr \& Rose, 1966), T. mannitofaciens (Onishi \& Suzuki, 1969), T. musae (Nakase, I97 I c), T. nemodendra (van der Walt et al. I97I b), T. peltata (Yarrow, I968), T. philyla (van der Walt et al. I97 I b), T. psychrophila (Goto et al. 1969) and T. silvatica (van der Walt et al. 1971 b). The list of species is incomplete since recently described species could not be included. Some earlier descriptions of species were not in the form used by Lodder (1970) and could not be applied to our system. Torulopsis peltata, although now transferred to the genus Selenotila (Yarrow, 1969 $b$ ), was retained in the analysis since no later examination was planned for that genus.

Computerized identification of Candida and Torulopsis species. Identification of species of Saccharomyces and Kluyveromyces was conveniently accomplished by computer program 2 (Campbell, 1973 $b$ ) but extension of the method to other genera increased to an inconvenient number the descriptions to be handled during each identification. A new program 3 compared the description of each unknown strain with all standard descriptions held in the data store; the names and matching coefficients of only the three highest matches were printed. Provided the highest match was $\geqslant 85 \%$ this was normally accepted as identification.

\section{RESULTS}

Initially the genera Candida and Torulopsis were examined separately. In the analysis of the 48 species of the genus Torulopsis the entire genus was examined in a single test by 


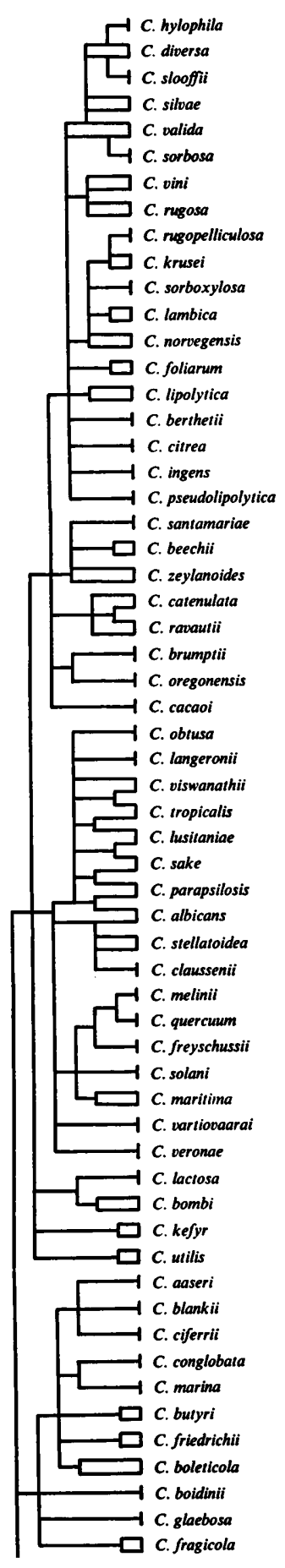

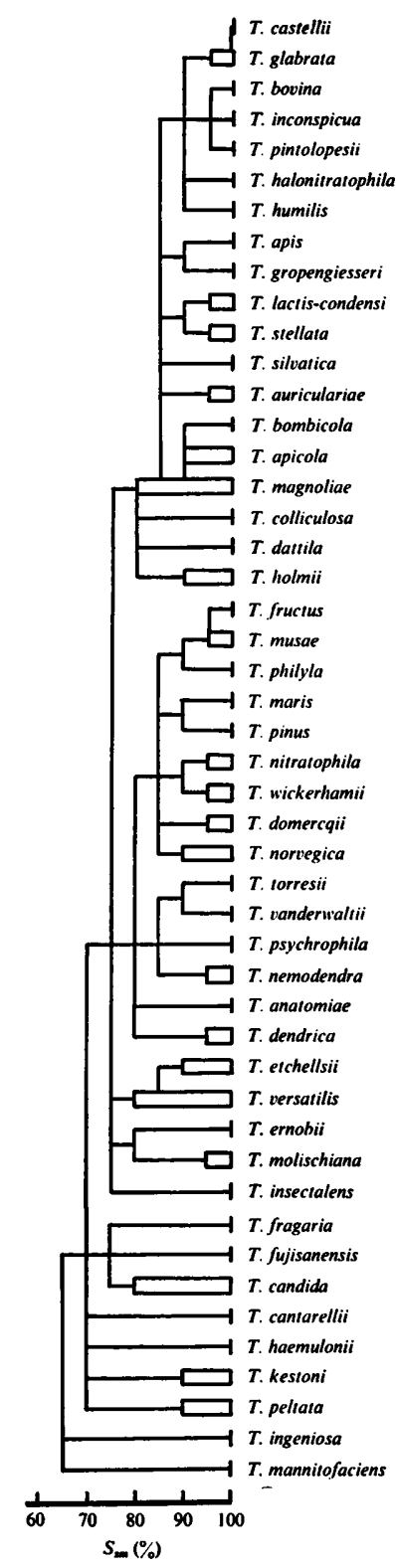

Fig. 2 


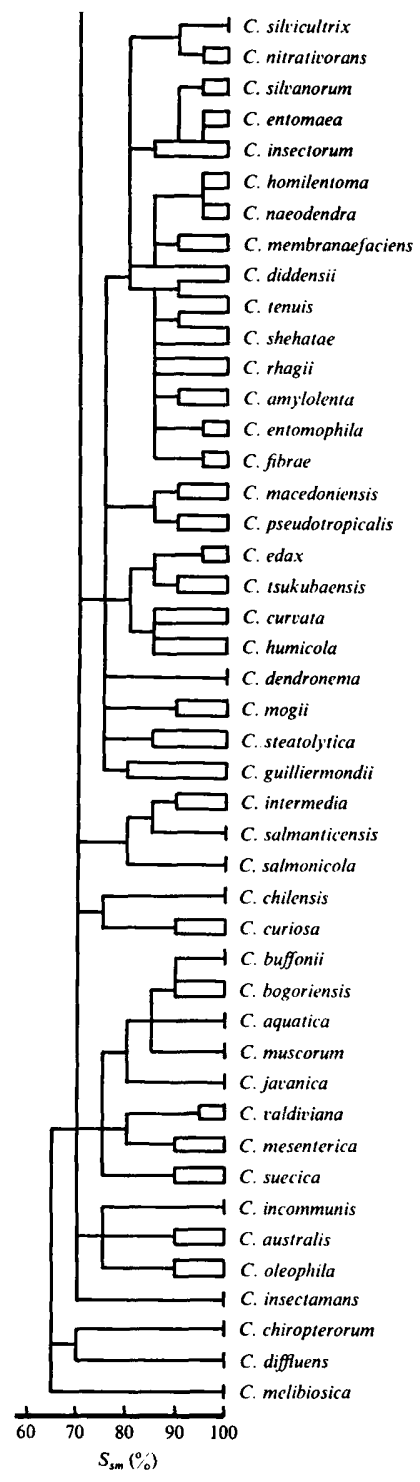

Fig. 1

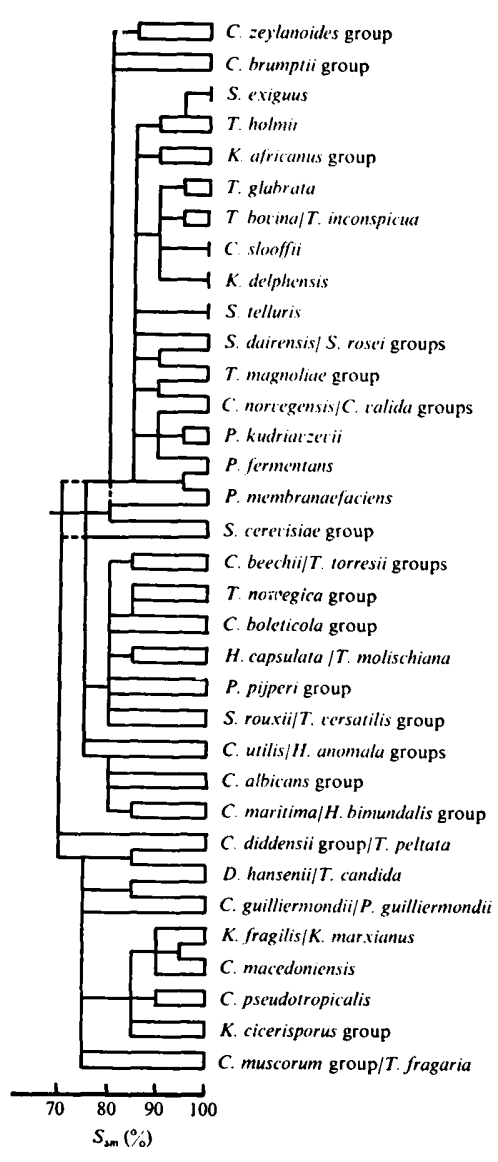

Fig. 3

Fig. I. Taxonomic dendrogram of 104 species of the genus Candida, from analysis of standard descriptions of species.

Fig. 2. Taxonomic dendrogram of 48 species of the genus Torulopsis, from analysis of standard descriptions of species.

Fig. 3. Dendrogram of selected taxonomic groups to show relationships between species or groups of the genera Candida, Debaryomyces, Hansenula, Kluyveromyces, Pichia, Saccharomyces and Torulopsis. 

program 2 (Campbell, 1973 $b$ ); the groups of species thus detected were confirmed, or adjusted as necessary, by analysis of batches of 24 cards by program I (Campbell, $1973 b$ ). The large number of species in the genus Candida was beyond the capacity of a single examination by program 2. Candida species were examined in various combinations in groups of approximately 50 species; by four separate analyses the relationship of each species was shown to all other species of Candida. Again, the validity of the taxonomic groups so detected was confirmed by analysis of smaller groups. Dendrograms of these analyses are shown as Figs. I and 2.

In the genus Candida, clusters of six or more species were associated with $C$. valida, $C$. albicans, C. maritima, C. boleticola and C. diddensii (Fig. I). Numerous smaller groups of 3 to 5 species were also noted. In the genus Torulopsis, 34 of the 48 species belonged to two main groups of species, related within each group at $S_{s m}>80 \%$ (Fig. 2). If species at $S_{s m}$ $\geqslant 90 \%$ are regarded as synonymous, in accordance with our system for other genera (Campbell, 1972, 1973a), the genus Candida should be reduced from 104 to 78 valid species and the genus Torulopsis from 48 to 33 species.

Each species of the genus Candida or Torulopsis was then compared with all species of the other genus and with the species already examined in the genera Debaryomyces, Hansenula, Kluyveromyces, Lodderomyces, Pichia and Saccharomyces (Campbell, 1972, 1973a). All species of these genera, as defined by Lodder (1970), were included in the comparison by programs I and 2 (Campbell, $1973 \mathrm{~b}$ ). Only groups of species are included in the resulting dendrogram (Fig. 3), except where more detail was occasionally required to show the close relationship between species of different genera. The main overlap between Candida and Torulopsis occurs in the groups containing $C$. norvegensis, $C$. valida, $T$. glabrata and $T$. magnoliae; some species of the genera Kluyveromyces, Pichia and Saccharomyces are also included in this cluster, and this complex group of species is illustrated in detail in Fig. 3. Otherwise, there is surprisingly little overlap between the genera, but some examples of the occurrence of similar species in different genera are discussed below.

\section{DISCUSSION}

The dendrograms of the genera Candida and Torulopsis reveal close matching, $S_{s m}>90 \%$, between species which vary in their ability to assimilate nitrate as sole source of nitrogen. Current classification of the genera Candida (van Uden \& Buckley, 1970) and Torulopsis (van Uden \& Vidal-Leiria, 1970) does not recognize nitrate-variable species, but since variable species occur in other genera, e.g. Brettanomyces and Cryptococcus (Lodder, 1970), they are presumably acceptable also in Candida and Torulopsis. The only significant difference between $T$. lactis-condensi and $T$. stellata is the assimilation of nitrate by the former species. Guanine-cytosine (GC) proportions of DNA bases of both species are in the range $42 \cdot 0$ to $43 \cdot 7 \%$ (Nakase \& Komagata, I97I $a$ ) and the proton magnetic-resonance (p.m.r.) spectra are remarkably similar, although not identical (Gorin \& Spencer, 1970). With this supporting evidence, the very close taxonomic relationship, $S_{s m} 90 \%$, suggests that these two species should be regarded as a single nitrate-variable species. Other similar examples are also shown in Figs. I and 2. Thus, C. freyschussii and C. quercuum (nitrate-negative) are related at $S_{s m} 90 \%$ to $C$. melinii (nitrate-positive), and may be considered as synonyms; C. bogoriensis (nitrate-positive) and C. buffonii (nitrate-negative) are also closely related.

Another complex group includes $T$. halonitratophila, which is related at $S_{s m} 90 \%$ to, and therefore presumably synonymous with, a group of six nitrate-negative Torulopsis species. Of these species, $T$. castellii and $T$. glabrata differ only in fermentation of trehalose, which was not assessed in our tests, and therefore these species are identical in Fig. 2. Torulopsis 
bovina, $T$. inconspicua and $T$. pintolopesii are mutually related at $S_{s m} 95 \%$; their separation into three species by van Uden \& Vidal-Leiria (1970) was based on their different habitats and optimum temperatures for growth, but morphologically and physiologically there is insufficient difference to justify more than one species. Candida slooffii and Saccharomyces telluris are closely related to this group and may represent a single species (van Uden \& Buckley, 1970). In our results (Fig. 3) Kluyveromyces delphensis was also closely associated with this group.

In a taxonomic study of the genus (Kocková-Kratochvílová, 1973), strains of 22 species of Torulopsis, including five species previously transferred by van Uden \& Vidal-Leiria (1970) to other genera, were arranged in nine main groups. Although the range of characters chosen by Kocková-Kratochvílová differed in some respects from that used here, the results are substantially the same, especially in the close similarity of $T$. etchellsii and $T$. versatilis (Kocková-Kratochvílová's phenon 6) and T. apis, T. apicola, T. gropengiesseri and $T$. magnoliae (phenon 7). In both Kocková-Kratochvílová's and our results the main groups of Torulopsis species are related at 75 to $80 \%$. Torulopsis glabrata and T. pinus, and $T$. candida and $T$. wickerhamii were placed in the same phenons by Kocková-Kratochvílová and in different groups in Fig. 2, but the percentage matching between the species is approximately the same in both analyses. Kocková-Kratochvílová analysed individual strains, whereas this report is based on standard descriptions of species, but the general agreement of the results is very satisfactory.

Similarities between species of different genera. Van Uden \& Buckley (1970) noted a number of similarities between species of Candida and Torulopsis and perfect genera. They quoted some examples where Candida and Torulopsis were renamed when shown to form spores. Since these species are no longer regarded as Candida or Torulopsis, they are not included in the present analysis. Van Uden \& Buckley also listed a number of similarities between species of ascosporogenous genera and species still classified as Candida or Torulopsis, and most of these similarities have been noted in the present analysis (Fig. 3). Thus, the $C$. norvegensis and $C$. valida groups are related to, and overlap considerably with, Pichia fermentans, $P$. kudriavzevii and P. membranaefaciens. Van Uden \& Buckley (1970) suggested that $C$. macedoniensis is the imperfect stage of Kluyveromyces marxianus, and C. pseudotropicalis is the imperfect form of $K$. fragilis. The close similarity of these four species is confirmed, but in Fig. 3 both Kluyveromyces species are most closely related to, or are possibly the imperfect stage of $C$. macedoniensis. Although not shown in Fig. 3, there was a close match, $S_{s m} 80$ to $90 \%$, between Lodderomyces elongisporus and members of the C. albicans group, including C. albicans itself; van Uden \& Buckley (1970) commented only on similarity to $C$. parapsilosis.

Other instances of closely matched species of different genera are apparent in Fig. 3, and others were shown in the more extensive results from which that dendrogram was prepared. Various groups of Candida, Debaryomyces, Kluyveromyces, Pichia, Saccharomyces and Torulopsis overlap, so that in one area there is a complex cluster of perfect and imperfect, weakly fermentative and non-fermentative, and pseudomycelial and non-mycelial yeasts. For the following associated species the matching is sufficiently close $\left(S_{s m} \geqslant 90 \%\right)$ to suggest synonymy, or a perfect/imperfect relationship: $C$. beechii/T. torresii, $C$. guilliermondii/Pichia guilliermondii, $C$. foliarum/T. silvatica (included in $C$. norvegensis and T. magnoliae groups respectively), C. muscorum/T. fragaria, Hansenula capsulata/T. molischiana, $K$. delphensis/T. glabrata/T. inconspicua. The suggested synonyms $C$. foliarum and $T$. silvatica not only belong to different genera owing to the primitive mycelium of $C$. foliarum, but differ in ability to assimilate nitrate. 
Other matchings in the 80 to $90 \%$ range, and therefore not close enough to suggest synonymy, may nevertheless be of interest. Torulopsis candida, itself showing a considerable range of variation within the description of the species, is similar to $C$. glaebosa and $C$. guilliermondii, but is probably the imperfect form of one or both species Debaryomyces hansenii and D. marama (van Uden \& Vidal-Leiria, 1970). Torulopsis stellata shows some similarity to Saccharomyces rosei, but is not sufficiently close to confirm van Uden \& VidalLeiria's (1970) suggestion that $S$. rosei and $T$. stellata are synonymous. Members of the $S$. rosei group (Campbell, 1972) are equally closely related to $T$. colliculosa $\left(S_{s m}\right.$ approximately $85 \%$ ); GC, p.m.r. and serological results (Nakase \& Komagata, 197I $a, b$; Gorin \& Spencer, 1970; Campbell, I97I; Tsuchiya, Fukazawa \& Kawakita, 1965) confirm a close relationship.

Main groups of Candida and Torulopsis species. Although the type of habitat from which the species were isolated was not considered in the analyses, most groups of species in Figs. $I$ and 2 show some ecological similarity.

The $C$. valida, C. norvegensis and C. zeylanoides group comprises 27 non-fermentative species, or species which ferment only glucose, usually weakly. These species have been isolated from a wide range of habitats. Many are associated with spoilage of foods and drinks; others are mammalian or insect parasites. Candida krusei, C. lambica, C. norvegensis and $C$. zeylanoides have been isolated from both types of habitat. The 27 species show a strong resemblance to the $P$. membranaefaciens group of species, e.g. C. krusei and $C$. valida are imperfect forms of $P$. kudriaveevii and $P$. membranaefaciens respectively (van Uden \& Buckley, 1970). The evidence in this paper of a relationship between the species of the group is supported by the similarity of the p.m.r. spectra: many of the species were examined by Gorin \& Spencer (1970) and belong mainly to p.m.r. groups I, 9, I5 and I8. GC proportions (Nakase \& Komagata, 197I c ) are very close in the members of the various subgroups of the cluster, e.g. C. lipolytica and C. rugosa (48.3 to $50 \cdot 7 \%$ ), but over the whole group the GC proportion rises from $34.4 \%$ (C. diversa) to $55.9 \%$ (C. zeylanoides) (Nakase \& Komagata, I97I $c$ ).

The $C$. albicans group comprises ten species related at $S_{s m} \geqslant 85 \%$, and a further seven species (C. maritima subgroup) related at $S_{s m} 80 \%$ to $C$. albicans. With the exception of C. sake, all species of the group are parasitic on humans or animals, although not necessarily in association with obvious disease. Most species of the group ferment a range of sugars, but none assimilate nitrate as nitrogen source. Numerical analyses of this group have consistently shown that the species merge as a cluster of overlapping species, as with $C$. lusitanide and C. sake in Fig. I (e.g. Kocková-Kratochvílová et al. 1967; Shechter et al. 1972).

The $C$. boleticola group comprises I I species mutually related at 75 to $85 \%$. There appears to be little ecological significance in this group; the members have been isolated from a wide range of habitats. Except for $C$. friedrichii, they are non-fermentative.

The $C$. diddensii group comprises I 5 species associated with insects, although $C$. diddensii, C. membranaefaciens and C. tenuis have also been isolated from other environments. All species of this group are weakly or non-fermentative.

In the final part of the dendrogram (Fig. I), C. chiropterorum, C. diffluens and C. melibiosica are shown to be related at only 55 to $65 \%$ to the rest of the genus Candida, casting doubt on their validity as Candida species. However, there are no properties which obviously distinguish them from other Candidae. Otherwise, the remaining species of Candida are sufficiently closely related $\left(S_{s m} \geqslant 65 \%\right)$ to be considered as members of a single genus.

There is no obvious association of ecological types in the main groups of the genus Torulopsis. On the other hand, subgroups of the larger groups are often associated with a 
particular environment: $T$. apis and $T$. gropengiesseri, which are probably synonymous, are both associated with insects, as are T. apicola, T. bombicola and some strains of T. magnoliae. Torulopsis fructus and T. musae, related at $S_{s m} 95 \%$, were both isolated (Nakase, I97I $c$ ) from bananas and represent strains of the same species.

Computerized identification. Standard descriptions were prepared for computerized identification of Candida and Torulopsis species using the same order of characters as for identification of species of Saccharomyces and Kluyveromyces (Campbell, 1973 $b$ ), and Brettanomyces, Debaryomyces, Endomycopsis, Hansenula and Pichia (unpublished results). Although 58 characters had been used for identification of Saccharomyces and Kluyveromyces species, insufficient information was available for inclusion of the final eight characters in descriptions of the other genera. Existing data on serological properties, hydrolysis of tributyrin, clearing of chalk, and tolerance of high concentrations of ethanol were incomplete and were therefore not used.

Each distinct species was represented by at least one standard description for identification. Each group of 2 to 4 species related at $S_{s m} \geqslant 90 \%$ in Figs. I and 2 was regarded as a single valid species, to be represented by a single description. In the larger clusters, including C. albicans, C. diddensii and T. glabrata, descriptions differing by $15 \%$ or more (cf. Campbell, $1973 b$ ) were prepared by trial and error. In those preliminary tests all matches over $85 \%$ were reduced by eliminating one of the species of the pair, or by altering the descriptions to reduce the matching coefficient to $\leqslant 85 \%$; all adjustments were made within the recognized range of properties of the species. When species were combined as synonyms, an average description was prepared to represent the new species. Thus, $T$. apis and $T$. gropengiesser $i$ were re-defined as one valid species ( $T$. gropengiesseri, by the normal rules of priority) but the mean standard description did not coincide exactly with the description of $T$. gropengiesseri sensu van Uden \& Vidal-Leiria (1970). In this respect the system differs from that of Barnett \& Pankhurst (1974), who provided a description of every physiological type which could occur within the standard description of the species; in our system only a single description of a hypothetical mean organism is normally required (Campbell, 1973 $b$ ).

The extension of the identification scheme from Saccharomyces and Kluyveromyces to other genera introduced the difficulty of distinguishing species related at $S_{s m}>85 \%$, but of different genera. After some attempts to remove or adjust descriptions of Candida and Torulopsis species to avoid close matching with species of perfect genera, such a system was rejected as both misleading and unnecessary. In our present system, within each genus no species are closer than $S_{s m} 85 \%$, but higher matching coefficients are tolerated between species of different genera. Normally, a culture is identified as the species whose standard description it matches most closely. Closely related descriptions of perfect and imperfect yeasts introduced the possibility of two valid highest matches in different genera. Thus, if the best matching coefficients are, for example, Candida krusei $96 \%$ and P. kudriavzevii $93 \%$, the culture is reported simply as C. kruseilP. kudriavzevii (cf. Beech et al. 1968). Higher matching with the imperfect species, as in the example, does not necessarily indicate an asporogenous yeast. Subsequent examination for spores may be performed if desired, but is not included in the computer identification.

Based on the analyses described above and in earlier papers (Campbell, I973 $a, b$ ), a selection of mean standard descriptions was prepared for identification of the genera Brettanomyces (including Dekkera), Candida, Endomycopsis, Hansenula (including Citeromyces and Pachysolen), Pichia (including Debaryomyces and Wingea), Saccharomyces (including Kluyveromyces) and Torulopsis. The system has given good agreement with identifications by Lodder (1970) and Barnett \& Pankhurst (1974). Since the system is still 
in the process of modification and improvement the descriptions of species are not presented here, but a list of the present computer descriptions of species is available on request.

I thank Miss Alison Gray and Miss Sally J. Marr for technical assistance, and Mr D. Cooper and $\mathrm{Mr}$ D. Taylor, of Heriot-Watt University Computer Centre, for assistance with computer techniques.

\section{REFERENCES}

BARNetT, J. A. \& BUhagiaR, R. W. M. (197I). Torulopsis fragaria, a yeast from fjuit. Journal of General Microbiology 67, 233-238.

Barnett, J. A. \& Pankhurst, R. J. (1974). A New Key to the Yeasts. Amsterdarn and London: NorthHolland.

Beech, F. W., Davenport, R. R., Goswell, R. W. \& Burnett, J. K. (1968). In Identification Methods for Microbiologists, part B, pp. 15I-175. Edited by B. M. Gibbs and D. A. Shapton. London and New York: Academic Press.

Blagodatskaya, V. \& Kocková-Kratochvíloví, A. (I973). The heterogeneity of the species Candida lipolytica, Candida pseudolipolytica $\mathrm{n}$. sp. and Candida lipolytica var. thermotolerans $\mathrm{n}$. var. Biologia, Bratislava 28, 709-716.

CampBell, I. (197I). Antigenic properties of yeasts of various genera. Journal of Applied Bacteriology 34, 237-242.

CAMPBeLl, I. (1972). Numerical analysis of the genera Saccharomyces and Kluyveromyces. Journal of General Microbiology 73, 279-30I.

CAMPBell, I. (I973a). Numerical analysis of Hansenula, Pichia and related yeast genera. Journal of General Microbiology 77, 427-44I.

CAMPBell, I. (I973b). Computer identification of yeasts of the genus Saccharomyces. Journal of General Microbiology 77, $127-135$.

DwiDJoseputro, D. \& Wolf, F. T. (1970). Microbiological studies of Indonesian fermented foodstuffs. Mycopathologia et mycologia applicata 41, 2 I I-222.

Gorin, P. A. J. \& SPENCER, J. F. T. (I970). Proton magnetic resonance spectroscopy - an aid in identification and chemotaxonomy of yeasts. Advances in Applied Microbiology 13, 25-89.

Goto, S., Sugiyama, J. \& IIzuKa, H. (1969). A taxonomic study of antarctic yeasts. Mycologia 6x, 748-774.

Grinbergs, J. \& Yarrow, D. (1970). Two new Candida species: Candida chilensis sp. n. and Candida valdiviana sp. n. Antonie van Leeuwenhoek 36, I43-148.

Grose, E. S. \& MARinKelle, C. J. (1968). A new species of Candida from Colombian bats. Mycopathologia et mycologia applicata 36, 225-227.

Kockoví-Kratochvíloví, A. (1973). Comparative taxonomy of the genus Torulopsis Berlese. Journal of General Microbiology 79, 239-256.

KockovÁ-KRATochvílovÁ, A. \& ONDRUšová, D. (1972). The grouping of species within the genus Candida Berkhout. In Yeasts: Models in Science and Technics, pp. 313-338. Edited by A. Kocková-Kratochvílová and E. Minárik. Bratislava: Slovak Academy of Sciences.

Kocková-Kratochvílová, A., Šandula, J., Vojtková, A., Pokorná, M. \& Stuchlík, V. (1967). The genus Candida Berkhout. VIII. Fermentation type II species. Folia microbiologica (Praha) 12, 327-344.

LODDER, J. (1970). The Yeasts, a Taxonomic Study, 2nd edn. Amsterdam and London: North-Holland.

Montrocher, R. (1967). Quelques nouvelles espèces et variétés du genre Candida (levures asporogènes). Revue de mycologie 32, 69-92.

NAKASE, T. (I97I $a$ ). Four new yeasts found in Japan. Journal of General and Applied Microbiology, I7, 469-478.

NAKASE, T. (197I $b$ ). New species of yeasts resembling Candida krusei (Cast.) Berkhout. Journal of General and Applied Microbiology r 7, 383-398.

NAKASE, T. (197I c). New species of yeasts found in Japan. Journal of General and Applied Microbiology 17, 409-419.

NAKASE, T. \& Komagata, K. (1971 $a$ ). Significance of DNA base composition in the classification of the yeast genus Torulopsis. Journal of General and Applied Microbiology 17, 16 I-166.

Nakase, T. \& Komagata, K. (197I $b$ ). Significance of DNA base composition in the classification of the yeast genus Saccharomyces. Journal of General and Applied Microbiology 17, 227-238. 
NaKase, T. \& Komagata, K. (I97I c). Significance of DNA base composition in the classification of the yeast genus Candida. Journal of General and Applied Microbiology 17, 259-279.

NeL, E. E. \& VAN DER WALT, J. P. (1968). Torulopsis humilis sp. n. Mycopathologia et mycologia applicata 36, 94-96.

Ohara, Y., Nonomura, H. \& YamazaKI, T. (1965). Candida incommunis sp. nov., a new yeast isolated from grape must. Journal of General and Applied Microbiology II, 273-275.

ONISHI, H. (1972). Candida tsukubaensis sp. n. Antonie van Leeuwenhoek 38, 365-367.

ONISHI, H. \& SUZUKI, T. (1969). Torulopsis mannitofaciens sp. n. isolated from soy-sauce mash. Antonie van Leeuwenhoek 35, 258-260.

Rodrigues de Miranda, L. \& Norkrans, B. (1968). Candida suecica sp. $n$. isolated from marine environment. Antonie van Leeuwenhoek 34, I 1 5-I 18.

SCARR, M. P. \& RoSE, D. (I966). Study of osmophilic yeasts producing invertase. Journal of General Microbiology 45, 9-16.

Shechter, Y., Landau, J. W. \& Dabrowa, N. (1972). Comparative electrophoresis and numerical taxonomy of some Candida species. Mycologia 64, 84I-85I.

Sneath, P. H. A. \& Sokal, R. R. (I973). Numerical Taxonomy. San Francisco: Freeman.

Spencer, J. F. T., Gorin, P. A. J. \& Tulloch, A. P. (1970). Torulopsis bombicola sp. n. Antonie van Leeuwenhoek 36, 129-133.

TsuchiYa, T., Fukazawa, Y. \& KaWakita, S. (1965). Significance of serological studies on yeasts. Mycopathologia et mycologia applicata 26, I-15.

van Uden, N. \& Buckley, H. (1970). Genus 2. Candida Berkhout. In The Yeasts, a Taxonomic Study, 2nd edn, pp. 893-1087. Edited by J. Lodder. Amsterdam and London: North-Holland.

van Uden, N. \& VIDAL-LeIRIA, M. (1970). Genus IO. Torulopsis Berlese. In The Yeasts, a Taxonomic Study, 2nd edn, pp. 1235-1308. Edited by J. Lodder. Amsterdam and London: North-Holland.

VAN DER WALt, J. P., Johannsen, E. \& NAKASE, T. (1973). Candida naeodendra, a new species of the Candida diddensii group. Antonie van Leeuwenhoek 39, 491-495.

van DeR WALT, J. P. \& NAKASE, T. (1973). Candida homilentoma, a new yeast from South African insect sources. Antonie van Leeuwenhoek 39, 449-453.

VAN DER WALt, J. P. \& Nel, E. E. (1968). Candida edax sp. n. Antonie van Leeuwenhoek 34, 106-108.

VAN DeR WALT, J. P., ScotT, D. B. \& VAN DeR KLIFT, W. C. (I97I $a$ ). Four new, related Candida species from South African insect sources. Antonie van Leeuwenhoek 37, 449-460.

VAN DeR WAit, J. P., Scott, D. B. \& VAN DeR KLIFT, W. C. (1971 b). Five new Torulopsis species from South African insect sources. Antonie van Leeuwenhoek 37, 46I-47I.

VAN DER WALt, J. P., SCOtT, D. B. \& VAN DER Klift, W. C. (1972). Six new Candida spp. from South African insect sources. Mycopathologia et mycologia applicata 47, 22 I-236.

YARRow, D. (1968). Torulopsis peltata sp. n. Antonie van Leeuwenhoek 34, 8I-84.

YARROW, D. (1969a). Candida steatolytica sp. n. Antonie van Leeuwenhoek 35, 24-28.

YARRow, D. (1969b). Selenotila peltata comb. n. Antonie van Leeuwenhoek 35, 418-420. 